Nig. J. Biotech. Vol. 36 (1): 171-176 (June 2019)

ISSN: 01891731

Available online at

http://www.ajol.info/index.php/njb/index

and www.biotechsocietynigeria.org

DOI: https://dx.doi.org/10.4314/njb.v36i1.22

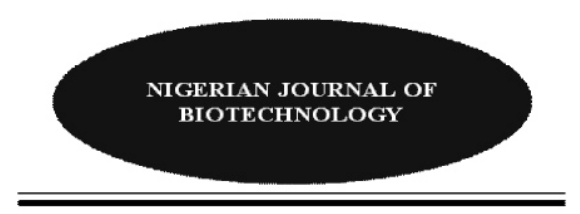

\title{
The use of immobilized microalgal bead concentrations in the removal of ammonium nitrogen from synthetic wastewater. \\ ${ }^{1,2}$ Oluwole, O. R., ${ }^{1}$ Tobin, C. M., ${ }^{4}$ Banjo, T. T., ${ }^{2}$ Efunwoye, O. O. and ${ }^{3}$ Awoyemi, S. 0.
}

${ }^{1}$ Faculty of Science and Engineering, University of Wolverhampton, United Kingdom.

${ }^{2}$ Department of Basic Sciences, Federal College of Agriculture, Akure, Ondo State.

${ }^{3}$ Department of Crop Production Technology, Federal College of Agriculture, Akure.

${ }^{4}$ Department of Biological Sciences, Wellspring University, Benin City, Edo State.

Copyright resides with the authors in terms of the Creative Commons License 4.0.

(See http://creativecommons.org/licenses/by/4.0/).

Condition of use: The user may copy, distribute, transmit and adapt the work, but must recognize the authors and the Nigerian Journal of Biotechnology.

\section{Abstract}

Removal of chemical pollutants has been important in the treatment of wastewater. The effect of Chlorella vulgaris (microalgae) on the removal of ammonium nitrogen $\left(\mathrm{NH}_{4}^{+}\right)$in synthetic wastewater (wastewater prepared in the laboratory) was investigated. $C$. vulgaris cells were immobilized in calcium alginate beads to allow diffusion of nutrients but retention of the cells. Concentration of $C$. vulgaris cells used to treat wastewater were equivalent to $20 \mathrm{~g} / \mathrm{l}, 40 \mathrm{~g} / \mathrm{I}$ and $80 \mathrm{~g} / \mathrm{l}$ of wastewater and treatment was under laboratory conditions at $25 \pm 2{ }^{\circ} \mathrm{C}$. C. vulgaris was effective in the removal of $\mathrm{NH}_{4}{ }^{+}$from wastewater; at the end of 24 hours of treatment, there was reduction in the initial concentration of $\mathbf{N H}_{4}^{+}$ by $78 \%$ for $20 \mathrm{~g} / \mathrm{l}$. For $40 \mathrm{~g} / \mathrm{I}$ treatment, there was $97 \%$ reduction in $\mathrm{NH}_{4}{ }^{+}$and $91 \%$ reduction for $80 \mathrm{~g} / /$ treatment. After $43 \mathrm{hr}$ of treatment, there was further reduction in $\mathrm{NH}_{4}{ }^{+}$for $20 \mathrm{~g} / \mathrm{l}(86 \%)$, and $80 \mathrm{~g} / \mathrm{l}(93 \%)$ but $40 \mathrm{~g} / \mathrm{l}(97 \%)$ remained constant. The concentration of $C$. vulgaris that showed the best activity in removing $\mathrm{NH}_{4}^{+}$from wastewater was $40 \mathrm{~g} / \mathrm{l}$.

Key words Microalgae, immobilize, microalgae, bead concentrations, ammonium nitrogen.

\section{Introduction}

Wastewater from domestic and industrial activities contain nutrients which support the growth of algae in water bodies. Wastewater released into streams without nutrient removal leads to the excessive growth of algae; this brings about the reduction of dissolved oxygen in water bodies and aquatic animals die of suffocation (Jia and Yuan, 2016; Madigan et. al., 2009). Due to this, it has become an obligation for industries to remove nutrients from wastewater before it is discharged into streams (De-bashan and Bashan, 2004).

Primary and secondary treatment of wastewater is less effective in removing dissolved nutrients. This has led to the use of tertiary treatment of wastewater such as: chemical flocculation, ammonia stripping, filtration, electron dialysis and ion exchange which are expensive (Cheremisinoff, 2002; Radojević and Bashkin, 1999). However, the use of microalgae as a tertiary treatment of wastewater has been found to be economical (Hosam et al., 2015; De- Bashan, 2004; JiménezPérez, 2003). Microalgae can be used to remove phosphorus, nitrogen, heavy metals and pathogens from wastewater (Junping, 2017; Munoz and Guieysse, 2016). Other advantages of using microalgae to treat wastewater include: prevention of sludge handling problems; microalgae used in treating wastewater can also be used as fertilizer (Jing, 2007), the photosynthetic activity of microalgae releases oxygen into the water bodies for the use by aquatic organisms and it does not require any 


\section{Oluwole et al./ Nig. J. Biotech. Vol. 36 Num. 1: 171-176 (June 2019)}

carbon source for it to remove nutrients from wastewater (Aslan and Kapdan, 2006).

Microalgae entrapped or immobilized within polymers can remove nutrients efficiently and can be easily harvested (Jyothi, 2016; Abdel Hameed, 2007).This was shown for Chlorella vulgaris cells trapped in calcium alginate spherical beads (Tam and Wong, 2000). The advantages of entrapping microorganisms within polymer are: retention time of cells in the reactor is prolonged, metabolic activity of the cells is maintained for long periods (Travieso et al., 1996), protection of entrapped microorganism from toxic substances in the wastewater by the polymers, increased nutrient removal is achieved because the population of the microorganisms increase within the polymer, competition of the entrapped microorganism with other microorganism in the wastewater is avoided and native microorganisms in the wastewater are prevented from competing with entrapped genetically modified microbes (Luan et al., 2006; Lau, 1996).

In view of these advantages, there are certain factors which determine the successful removal of nutrients by immobilized microalgae. One of these factors is bead concentration. It has been reported that too high and too low bead concentrations were not effective in nutrient removal (Tam and Wong, 2000). Too low bead concentration implies low cell concentration for the treatment of wastewater and self-shading effects of dense bead concentration prevent proper light penetration into the bioreactor and the metabolic activity of the microalgae is thereby affected. There is need to determine the optimal bead concentration required to obtain the most cost effective removal of nutrient during treatment of wastewater. In this study, the effect of varying bead concentrations on nutrient removal from synthetic wastewater was investigated in order to determine the concentration of beads that is cost effective for the treatment of synthetic wastewater.

\section{Materials and Methods}

Microalgae and culture conditions

A pure culture of $C$. vulgaris was obtained from the Culture Collection of Algae and Protozoa
(CCAP), 211/11B, United Kingdom was used. The stock culture was grown at $23 \pm 2^{\circ} \mathrm{C}$ and sunlight was the source of light energy in four $50 \mathrm{ml}$ conical flasks in sterile Bold's Basal Medium (BBM) as described by (Dawson, 2010). $10 \mathrm{ml}$ of the pure stock suspension of C. vulgaris was inoculated into $90 \mathrm{ml}$ of sterile BBM in three conical flasks on a mechanical shaker at 120 revolutions per minute (r.p.m.) and was cultured day and night at $26^{\circ} \mathrm{C}$ for $6-8$ days. The source of light was four $40 \mathrm{~W}$ fluorescent tubes.

\section{Immobilization of C. vulgaris in alginate beads}

C. vulgaris cells were immobilized by using the method described by (De-bashan, 2004). Algal biomass was harvested by centrifugation at $2000 \mathrm{~g}$ for 10 minutes. The harvested cells were washed twice with sterile $\mathrm{NaCl}$ solution $(0.85 \%)$. The washed cells were suspended in $15 \mathrm{ml}$ of the same sterile $\mathrm{NaCl}$ solution and was added to sterile $2 \%$ sodium alginate solution. The microorganisms and $2 \%$ alginate solution was mixed gently to minimize cell damage by turning the schott bottle upside down for four times to yield a $2 \%$ algal alginate suspension. The algal alginate suspension was allowed to drop from a tube that has an internal diameter of $4 \mathrm{~mm}$ into a sterile $2 \% \mathrm{CaCl}_{2} \cdot 2 \mathrm{H}_{2} \mathrm{O}$ (hardener) in a conical flask (Plate $\mathrm{A}$ ). The clip of the tube was adjusted to allow a drop of algal suspension per second. The bubbles were removed by running algal alginate suspension through the apparatus before bead formation. The cells were thus immobilized in beads of $4 \mathrm{~mm}$ in diameter. The beads were allowed to harden in $2 \% \mathrm{CaCl}_{2} . \mathrm{H}_{2} \mathrm{O}$ for 25 minutes. The conical flask containing the hardener was placed on the orbital shaker to give calcium chloride solution a swirling movement so as to aid easy formation of spherical beads. The algal alginate beads were washed with sterile $0.85 \% \mathrm{NaCl}$ to remove traces of $\mathrm{CaCl}_{2} \cdot 2 \mathrm{H}_{2} \mathrm{O}$. Alginate beads were inoculated into wastewater immediately after making them in order to avoid death of cells. 
Oluwole et al./ Nig. J. Biotech. Vol. 36 Num. 1: 171-176 (June 2019)
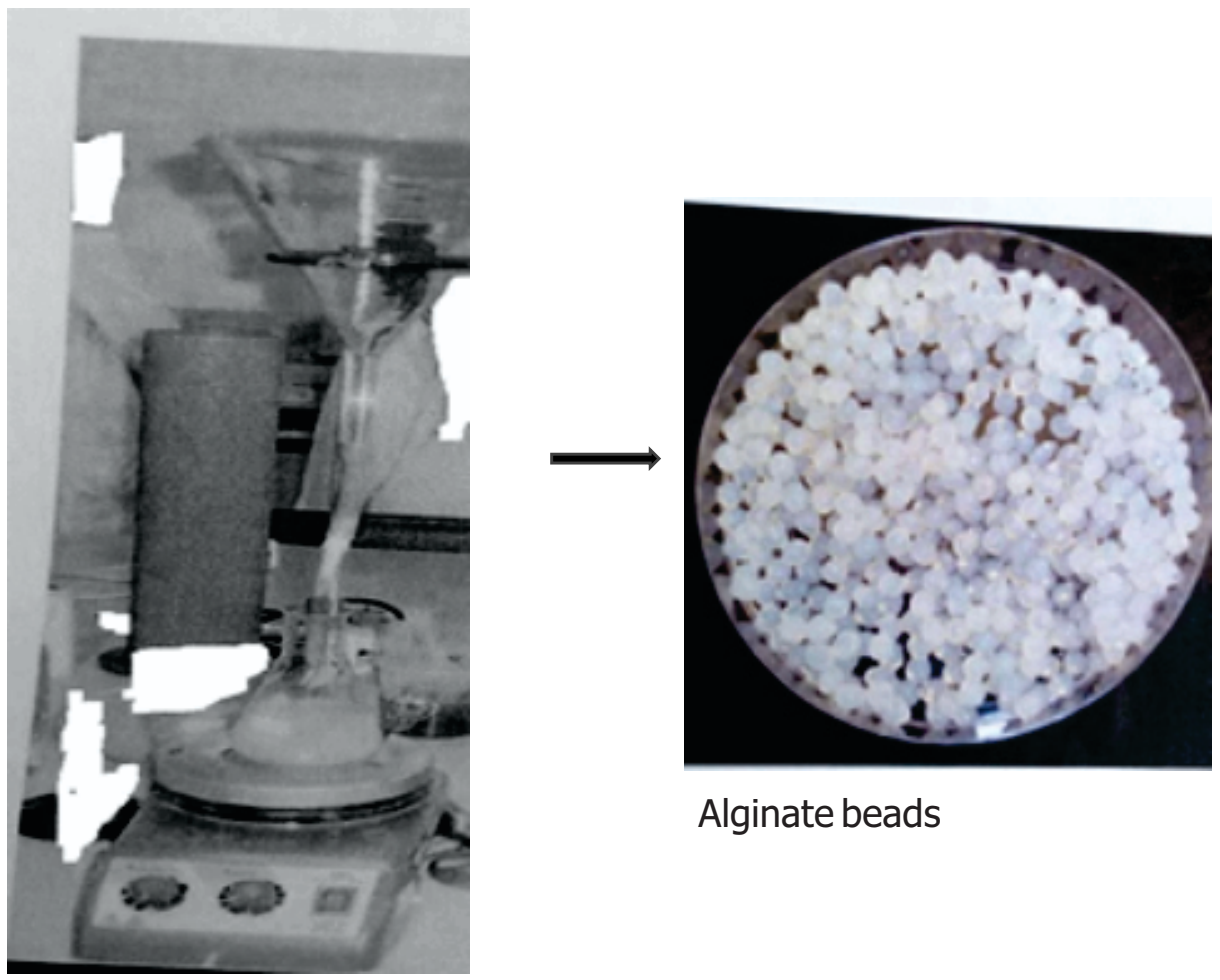

Alginate beads

Funnel and beaker

Plate A: Production of alginate beads (Brook, 2000).

A liter of synthetic wastewater was prepared based on the recipe of (De-bashan et al., 2004). Stocks of $2.17 \mathrm{~g} / 100 \mathrm{ml}$ phosphate-P as $\mathrm{K}_{2} \mathrm{HPO}_{4}, 0.1 \mathrm{~g} / 100 \mathrm{ml}$ ammonium- $\mathrm{N}$ as $\mathrm{NH}_{4} \mathrm{Cl}$, $0.40 \mathrm{~g} / 100 \mathrm{ml} \mathrm{CaCl}, 0.20 \mathrm{~g} / 100 \mathrm{ml} \mathrm{MgSO}_{4}, 0.70$ $\mathrm{g} / 100 \mathrm{ml} \mathrm{NaCl}, 0.85 \mathrm{~g} / 100 \mathrm{ml} \mathrm{KH}_{2} \mathrm{PO}_{4}$, and 3.34 $\mathrm{g} / 100 \mathrm{ml} \mathrm{Na}_{2} \mathrm{HPO}_{4}$ was prepared separately and 1 $\mathrm{ml}$ of each stock solution was added to $993 \mathrm{ml}$ of distilled water to make a litre. The stocks were used immediately for the preparation of wastewater. The $\mathrm{pH}$ of the wastewater was 6.77. Wastewater was sterilized in an autoclave and treated with the immobilized C.vulgaris immediately after cooling.

\section{Bioreactor and sampling}

The experiment was in three stages, the first stage consist of six conical flasks of $250 \mathrm{ml}$ capacity, three of these conical flasks contained $95 \mathrm{ml}$ of wastewater only which was the control, another set of three contained $1.9 \mathrm{~g} / 95 \mathrm{ml}$ algal alginate beads/wastewater each, and the second and third experimental groups contained 3.8 $\mathrm{g} / 95 \mathrm{ml}$ and $7.6 \mathrm{~g} / 95 \mathrm{ml}$ algal alginate beads/wastewater respectively with the control. Three of the conical flasks were used for a triplicate of the treatment in which one treatment in a conical flask represented a replicate. The experiments in this study were carried out using batch culture. Sample of $10 \mathrm{ml}$ was taken for analysis from each of the three replicates of treatment and control (wastewater only without alginate beads) after 19 hours, 24 hours and 43 hours of wastewater treatment.

\section{Analysis of wastewater}

Initial concentration of $\mathrm{NH}_{4}^{+}$(ammonium nitrogen) in the wastewater was determined as well as after treatment of wastewater for 19 hours, 24 hours and 43 hours. The concentration of ammonium nitrogen was determined by using a photometer (Palin Test Kit, photometer 7100). The kit can detect ammonium ion concentrations between $0-1.0 \mathrm{mg} / \mathrm{l}$ using tablets that contains alkaline salicylate and a catalyst. $\mathrm{NH}_{4}{ }^{+}$ concentration was detected in $\mathrm{mg} / \mathrm{l}$ at phot 4 .

\section{Statistical Analysis}

The mean and standard error of the triplicates for each treatment and control were calculated. One-way Analysis of Variance (ANOVA) was used to evaluate the effect of different bead concentrations at a particular treatment time on ammonium nitrogen removal from synthetic wastewater. The statistical package used was the Statistical Package for Social Sciences (SPSS). The mean values of 
treatments and controls were compared by using the Duncan Multiple Range Test.

\section{Weighing of beads}

A weighing balance was used to weigh beads at different times by putting it on a petri dish that was placed on the weighing balance. Each of the $1.9 \mathrm{~g}, 3.8 \mathrm{~g}$ and $7.6 \mathrm{~g}$ beads weighed was added to $95 \mathrm{ml}$ of wastewater in three separate $250 \mathrm{ml}$ conical flask.

\section{Nutrient removal experiment}

Ninety five milliliters of wastewater was treated in a $250 \mathrm{ml}$ conical flask (bioreactor) with the immobilized $C$. vulgaris in a batch culture at 120 r.p.m. $26^{\circ} \mathrm{C}$ (day and night) and photosynthetic ally active radiation of 256 $\mu \mathrm{W} . \mathrm{cm}^{2}$ for 43 hours. Wastewater was inoculated with three different algal alginate bead concentrations which were $20 \mathrm{~g} / \mathrm{l}, 40 \mathrm{~g} / \mathrm{l}$ and 80 $\mathrm{g} / \mathrm{l}(\mathrm{w} / \mathrm{v})$ to wastewater. Wastewater treated with each bead concentration was from the same preparation and the sterile wastewater only was also subjected to the same conditions as the treated wastewater.

\section{Results}

The effect of different bead concentrations on the removal of ammonium nitrogen from synthetic wastewater

There was rapid reduction in the concentration of $\mathrm{NH}_{4}^{+}$in the first 19 hours of treatment using the three bead concentrations (Fig 1). There was $86 \%, 97 \%$ and $93 \%$ reduction in ammonium nitrogen at the end of the 43 hours experiment using $20 \mathrm{~g} / \mathrm{l}, 40 \mathrm{~g} / \mathrm{l}$ and $80 \mathrm{~g} / \mathrm{l}$ bead concentrations respectively. ANOVA result, $\mathrm{P}<0.05$ shows that there was significant reduction in ammonium nitrogen using the three concentrations at 24 hours of treatment. However, the mean value of $40 \mathrm{~g} / \mathrm{l}$ remained constant at 24 hours treatment time and at 43 hours treatment time.

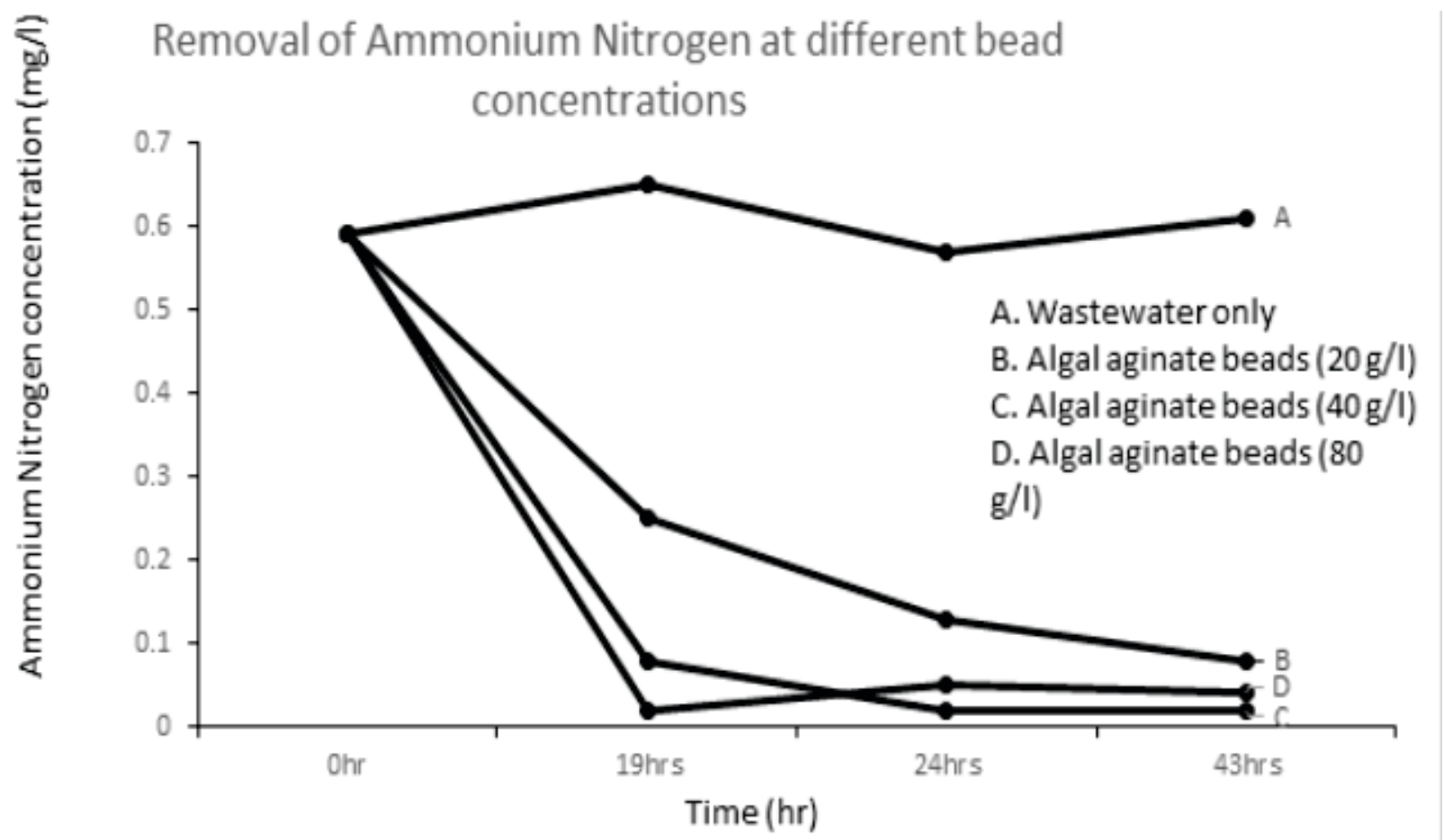

Fig 1: Ammonium Nitrogen Removal by different ( $20 \mathrm{~g} / \mathrm{l}, 40 \mathrm{~g} / \mathrm{l}, 80 \mathrm{~g} / \mathrm{l})$ bead concentrations.

\section{Discussion}

Immobilization of microalgae in alginate beads is a frequently used technique in wastewater treatment experiments (Jing et al., 2007). However, several factors determine the successful removal of nutrients by immobilized microalgae such as the gel matrix, $\mathrm{pH}$ of the wastewater, cell concentration and bead concentration (Zhang et al.,2007; Tam and
Wong, 2000; Radojević, and Bashkin, 1999). This study revealed that the three bead concentrations were effective in reducing the concentration of ammonium nitrogen in synthetic wastewater. At the end of the 43 hours experiment, $20 \mathrm{~g} / \mathrm{l}$ bead concentration removed $86 \%$ of the initial concentration, $40 \mathrm{~g} / \mathrm{l}$ bead concentration removed $97 \%$ of $\mathrm{NH}_{4}{ }^{+}$and $80 \mathrm{~g} / \mathrm{l}$ bead concentration removed $93 \%$ of 
$\mathrm{NH}_{4}{ }^{+}$. The least effective of the bead concentrations was $20 \mathrm{~g} / \mathrm{l}$, followed by $80 \mathrm{~g} / \mathrm{l}$ and $40 \mathrm{~g} / \mathrm{l}$ which is in accordance with (Tam and Wong, 2000) that states that too high and too low concentration of beads are not very effective. High bead concentration $(80 \mathrm{~g} / \mathrm{l})$ prevents proper light penetration into the bioreactor due to selfshading of dense beads. The metabolic activity and growth of the cells is thus affected. However, too low bead concentration $(20 \mathrm{~g} / \mathrm{l})$ implies a low concentration of cells available for the treatment of wastewater. The cell concentration available for the treatment of wastewater using $40 \mathrm{~g} / \mathrm{l}$ is probably the optimum cell concentration for the treatment of wastewater; according to (Zhang et al., 2007) the use of an optimum cell concentration is important for an effective removal of nutrients from wastewater.

The rapid and effective reduction of ammonium nitrogen in synthetic wastewater with immobilized microalgae in alginate beads suggests that the use of an optimum algal bead concentration in urban wastewater treatment plant will enhance compliance to European Union (EU) regulations that the total inorganic nitrogen concentration in the wastewater discharged from the plant should be less than $15 \mathrm{mg} / \mathrm{l}$ in environmentally sensitive areas (Jing et al., 2007).

In the present study, the removal of ammonium nitrogen was rapid and highly effective. This suggests that the utilization of ammonium nitrogen is essential to microalgae growth. Research has also revealed that the uptake of ammonium nitrogen by microalgae requires less energy compared to the uptake of urea and nitrate (Jia and Yuan, 2016).

In conclusion, the removal of ammonium nitrogen was highly effective using different algal bead concentrations. This was explained by (Radojević and Bashkin, 1999) that the uptake of nutrient by biomass is usually in the ratio 100:16:1 (Carbon: Nitrogen: Phosphorous). However, the optimum algal alginate bead concentration for the effective removal of ammonium nitrogen from synthetic wastewater is equivalent to $40 \mathrm{~g} / \mathrm{l} \mathrm{w} / \mathrm{v}$, which removed $97 \%$ ammonium nitrogen, followed by $80 \mathrm{~g} / \mathrm{l} \mathrm{w} / \mathrm{v}$, then, $20 \mathrm{~g} / \mathrm{l} \mathrm{w} / \mathrm{v}$ which removed $93 \%$ and $86 \%$ ammonium nitrogen respectively.

\section{References}

Abdel Hameed, M. S. (2007) Effect of algal density in bead, bead size and bead concentrations on wastewater nutrient removal. Afr. J. Biotechnol. 6(10):1185 - 1191

Aslan, S and Kapdan, K. I. (2006) Batch kinetics of nitrogen and phosphorous removal from synthetic wastewater by algae. Ecol Eng. 28(1):64-70.

Brook, A., Dawson, A. and Atkinson, E. (2000) BordnaMona: Bead Consultancy. Modified Method, 10 June 2010.

Cheremisinoff, N. P. (2002) Handbook of Water and Wastewater Treatment Technologies. $1^{\text {st }}$ ed. Butterworth-Heinemann

Dawson, A. (2010) University of Wolverhampton's recipe for Bold's Basal Medium, 2 June, 2010

De-bashan, L. E. and Bashan, Y. (2004) Recent advances in removing phosphorus from wastewater and its future use as fertilizer (19972003). Water Res. 38:4222-4246.

De-bashan, L. E., Hernandez, J., Morey, T. and Bashan, Y. (2004) Microalgae growth-promoting bacteria as "helpers" for microalgae: a novel approach for removing ammonium and phosphorus from municipal wastewater. Water Res. 38:466-474.

Hosam, A. S, Amr, M. A., Ahmed, M. B., and Abdel Mottaleb, M. S. A. (2015) Removal of Ammonia and Phosphate from Water Resources using Free and Immobilized Microalgae. Int. J. Environ. 4(3):193-203.

Jia, H. and Yuan, Q. (2016) Removal of nitrogen from wastewater using microalgae-bacteria consortia. Cogent Environ. Sci. 2:1275089. http://dx.doi.org/10.1080/233311843.2016.127 5089.

Jiménez-Pérez, M. V., Sánchez-Castillo, P., Romera, O., Fernández-Moreno, D and PérezMartinéz, C. (2003) Growth and nutrient removal in free and immobilized planktonic green algae isolated from pig manure. Enzyme Microb Technol. 34:392-398.

Jing, S., Björn, P. and Michael, M. (2007) Removal 
of nitrogen and phosphorus from wastewater using microalgae immobilized on twin layers: an experimental study. J. Appl. Phycol. 19:417-423.

Junping, L., Jia, F., Qi, L. and Shulian, X (2017) Microalgal Cultivation in Secondary Effluent: Recent Developments and Future Work. Int. J. Mol.Sci. 18:19; doi:10.3390/ijms18010079

Jyothi, K., Mohan, N. and Rao, G. (2016) Applications of immobilized algae. J. Algal Biomass UtIn. 7(2):122-128

Lau P. S., Tam N. F. Y. and Wong Y. S. (1996) Wastewater nutrients removal by Chlorella vulgaris: optimization through acclimation. Environ. Technol. 17(2):183-189.

Luan, T. G., Jin, J, Chan, S. M. N., Wong, Y. S. and Tam, N. F. Y. (2006) Biosorption and biodegradation of tributyltin (TBT) by alginate immobilized Chlorella vulgaris beads in several treatment cycles. Process Biochemi. 41(7):15601565

Madigan, T. M., Martinko, J. M., Dunlap, P. V. and
Clark, D. P. (2009) Biology of Microorganisms. $12^{\text {th }}$ ed. Pearson International Edition.

Munoz, R and Guieysse, B. 2006 Algal-bacterial processes for the treatment of hazardous contaminants: A review. Water Res. 40(15):2799-2815.

Radojević, M and Bashkin, V. N. (1999) Practical Environmental Analysis. $1^{\text {st }}$ ed. Royal Society of Chemistry

Tam, N. F. Y. and Wong, Y. S. (2000) Effect of immobilized microalgal bead concentrations on wastewater nutrient removal. Environ Pollut. 107:145-151.

Travieso, L., Benitez, F., Weiland, P., Sánchez, E., Dupeyron, R. and Dominguez, A.R. (1996) Experiments on Immobilization of Microalgae for Nutrient Removal in Wastewater Treatments. Bioresour Technol. 55:181-186.

Zhang, E., Wang, Q., Zhang, S. and Zhao, B (2007) Bioresour Technol. 99 (2008): 37873793. 